\title{
Mexx - An Attitude, A Lifestyle, A Kiss: A Case Study In Global Strategy
}

Judith Washburn, University of Tampa, USA

Hemant Rustogi, University of Tampa, USA

Rebecca Dearth, Advantage Pointe Internationale, LLC, USA

\begin{abstract}
This case explores the opportunities and challenges confronting Mexx in the early 21 st century. For more than 20 years, Mexx, an Amsterdam-based global retailer, grew quickly and successfully. Purchased by the Liz Claiborne organization in 2001, at the turn of the century, Mexx was poised for continued expansion and support to build a powerful, global retail brand. In 2008, Mexx management faces strategic decisions that will impact the company's future in the highly competitive global fashion arena.
\end{abstract}

Keywords: Mexx; Retail; Liz Claiborne; Rattan Chadha; Mexx Family Stores; MexxSport; XX by Mexx; Jeff Fardell; clothing

\section{INTRODUCTION}

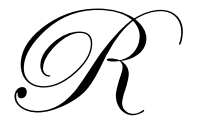

attan Chadha created the global fashion brand Mexx by combining two existing companies, Mustache and Emanuelle. What began as a family business grew into a global enterprise, with locations ranging from the United Kingdom to the Middle East. Under the company's parent company, Liz Claiborne, Mexx has had its successes and failures within the fashion industry. The 2008-2009 economic down turn resulted in Mexx struggling to compete and company executives making critical decisions to ensure Mexx's survival.

\section{A DECISION POINT (Late Summer 2008)}

When spoken aloud in Mandarin or Cantonese, the number "8" sounds like the word for "good fortune." The 2008 Olympics opened at 8:08 p.m. in Beijing on Friday, 08-08-08, reportedly because the date would be a good omen for the games. While watching the opening ceremonies on TV, Jeff Fardell silently wished for a bit of that Chinese good luck. Less than one year ago, Fardell had been quoted extensively as he discussed the rebirth of Mexx, a global fashion brand. Appointed in 2006 as the new President and CEO of Mexx Europe, Fardell was at a decision point in the late summer of 2008.

The state of the world economy in 2007 and 2008 was volatile, especially in the retail industry. Mexx appeared to be trapped in the dangerous middle -- the retail segment experiencing the worst decline. High end designer labels were, historically, somewhat recession-proof. The mid-level designer price points, like Mexx, were suffering. Worldwide, customers in Mexx's target segment -- 20-somethings to 40-year olds who sought style, but at an affordable price -- were losing their white color jobs and paying record high prices for gas, groceries and travel. Clothing purchases either stopped or moved noticeably down-scale. Having already pulled out of a much publicized, but failed, entry into the US market, Mexx had also just closed 28 UK stores, which had been open for barely one year.

As Fardell watched the stock price of Mexx's parent company, Liz Claiborne, Inc., inch up from its historical low point in the summer of 2008 (See Exhibit 1), he wondered where Mexx was left in this mix. 


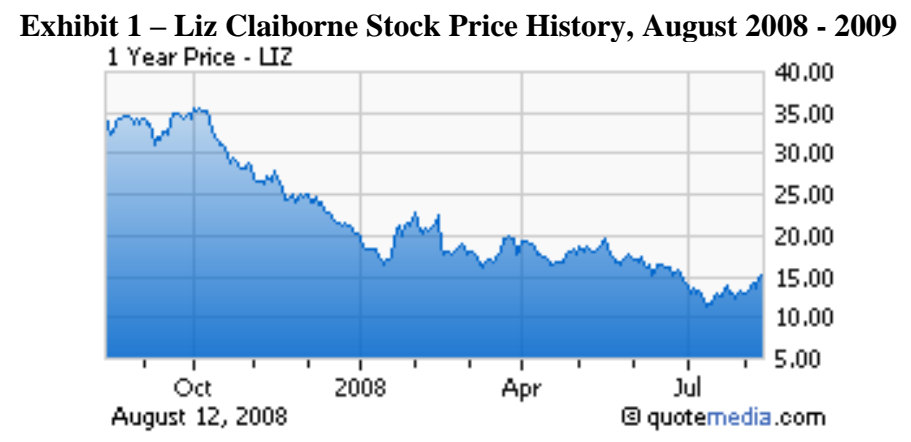

Mexx had been purchased by Liz Claiborne in 2001 in an acquisition frenzy, and its value soared along with Liz's until the end of 2006, at about the same time that Mexx founders sold their shares and Jeff Fardell joined the new team. Fardell reflected on the Mexx story as he grappled with the hard decisions he faced.

\section{CREATION AND MERGER (1980-2001)}

\section{Humble Beginnings}

"I started as a private-label business with $\$ 2000$. When someone asked how long it would take to get the clothes, I'd say 45 minutes, just the time it took to get to the car," explained Rattan Chadha ("Chada Taps Fardell," 2006). Chadha's first venture into the fashion industry involved clothes from his sister's garment factory in India. By 1980, Chadha had founded the Dutch companies Mustache (for men) and Emanuelle (for women). Each store was introduced with a clear cut identity that featured youthful fashion and a distinct lifestyle (www.mexx.com). Exhibit 2 details the Mexx timeline.

Chadha combined the two companies in 1986 to form Mexx, a name created by joining the " $\mathrm{M}$ " from Mustache with the "E" from Emanuelle, and sealed with two kisses, "XX." According to Chadha, Mexx was a brand building exercise from its inception ("Chada Taps Fardell," 2006). The new Mexx brand was launched with a print advertising campaign, "Here we are!" run in 85 magazines and 13 European and Far Eastern countries (www.mexx.com).

Short of operating funds and lacking a distinct identity, Mexx struggled in the early 1980's. Rattan Chaddha and the core management team of five boyhood friends who all graduated from Sherwood College, Nainital, an elite all boys high school in India, shared a simple philosophy. Ashish Sensarma, Mexx's Vice President for Consumer Sales until 2007, explained: "This is a family business and we celebrate each other's success with no jealousy and no back biting! Oh, and one other thing, none of the management team wives were allowed to work in the business so that the business dynamics were insulated from potential family infighting (Interview, 2006) "

In the early 1990s, Mexx began an aggressive product line expansion, introducing Mexx Kids for 2 to 8 year old boys and girls and Minimexx for toddlers (www.mexx.com). Over the next 10 years, Mexx continued rapid expansion debuting the Mexx brand in the Middle East and Canada, and expanding product lines even further to include:

- Mexx Family Stores - a collection of women's, men's and children's clothes under one roof

- MexxSport - a sport collection for fashion conscious women

- $\quad$ XX by Mexx - a younger, trendier Mexx sister brand

- Mexx licenses in European countries for such products as fragrances, shoes, socks, watches, handbags, eye glasses, bed \& bath and furniture for babies and toddlers (www.mexx.com) 
The strategy was conceived to position Mexx as a complete lifestyle brand, reaching Mexx customers for many of their product needs. This effort was reinforced by introducing Mexx.com and Mexx Connect, a customer loyalty program, in addition to further store expansion in Europe (www.mexx.com). Quality control was considered a key success factor. Mexx sourced product from more than 60 countries, particularly India and China, and controlled every quality dimension of the manufacturing process from design, to materials, to standards as detailed as specifying the thread count. The heart of the Mexx operation was its corporate office building located just outside of Amsterdam, in the Netherlands.

By the turn of the new century, Mexx had grown quickly and successfully into a trendy, moderately priced fashion house ("Recent Buy," 2001). In the spring of 2000, Mexx was planning an initial public offering in Amsterdam with the intention of boosting both wholesale and retail operations. Sales were increasing 25 percent per year and Mexx employed more than 1500 people with a total of 60 stores in the Benelux countries and Germany. Mexx sold clothing and accessories in more than 40 countries through licensing deals and was making plans to sell direct to consumers through Mexx.com ("Fashion Group Mexx," 2000). During 2000, Mexx opened ten new stores and reported plans to build a total of 500 stores throughout Europe ("Mexx Sees Profit Rise," 2001). MexxJewels was launched in several European countries, MexxFragrances was re-launched in a licensing partnership, and MexxSports began to sponsor women's tennis and golf competitions. The Mexx lifestyle brand was thriving as the world entered a new millennium (www.mexx.com).

Exhibit 2 - Mexx Company Timeline

\begin{tabular}{|c|c|}
\hline 1970s & Rattan Chadha supplies department stores and wholesalers with custom designed clothing \\
\hline 1980 & Mustache and Emanuelle are born with clear cut fashion identities, focusing on lifestyle, youthful fashion \\
\hline 1986 & Chadha combines Mustache and Emanuelle to create Mexx \\
\hline 1987 & Mexx opens its corporate center in an old silver factory in Voorschoten, The Netherlands \\
\hline 1990 & Mexx Kids launched for 2-8 year old boys \& girls \\
\hline 1992 & Minimexx for toddlers introduced \\
\hline 1995 & Flagship store opens in Montreal, Canada \\
\hline 1996 & $\begin{array}{l}\text { Mexx Family Store concept opened in Ghent, Belgium housing collections of Mexx Women, Men and Youth; } \\
\text { First Lifestyle store opens in Antwerp; Babymexx is born for 0-6 months }\end{array}$ \\
\hline 1997 & $\begin{array}{l}\text { MexxSport, a sport collection for fashion conscious women introduced; XX, the younger, trendy sister of Mexx, } \\
\text { introduced; Licenses products, including: Fragrance, Shoes, Time, Bags, Eyes, Bed \& Bath, Minimexx Home } \\
\text { (furniture for babies \& toddlers), Socks }\end{array}$ \\
\hline 1998 & Flagship Antwerp store opened \\
\hline 1999 & $\begin{array}{l}\text { Mexx.com is launched to offer views of product portfolio, image, philosophy, news, store finder and QTVR; } \\
\text { Flagship stores in London, Cologne, Hamburg and Utrecht open in prime shopping locations }\end{array}$ \\
\hline 2000 & $\begin{array}{l}\text { Launch MexxJewels in Netherlands, Belgium, Germany and Scandanavia; Relaunch of Fragrances with licensing } \\
\text { partner - Cosmopolitan Cosmetics }\end{array}$ \\
\hline 2001 & $\begin{array}{l}\text { Liz Claiborne acquires all Mexx stock for } 300 \text { million Euro in cash; Launch MexxHome mail order catalog and } \\
\text { eShop in Germany; Mexx Sport Xperience, Europe's largest indoor workout event opens }\end{array}$ \\
\hline 2002 & $\begin{array}{l}\text { First megastore opens in Berlin with complete product offering under one roof, a coffee/juice bar, a lounge and } \\
\text { free I-net access; MexxColors cosmetic line is launched in exclusive deal with Etos pharmacies to match new } \\
\text { season Mexx apparel colors; XX opens first stand-alone store in Prague }\end{array}$ \\
\hline 2003 & $\begin{array}{l}\text { MexxSport Men introduced; Two more mega stores open in Belgium - Brussels and Antwerp; XX by Mexx Jeans } \\
\text { introduced; Three US stores open New York; International Design Center in Amsterdam announced }\end{array}$ \\
\hline 2004 & $\begin{array}{l}\text { Debuted brand lifestyle magazine in } 4 \text { languages; Opened International Design Center and integrated Liz } \\
\text { Claiborne brands }\end{array}$ \\
\hline 2005 & $\begin{array}{l}\text { Premium jeans brand launched; Mexx Oxford store opens a new concept store, largest store in the UK; XX by } \\
\text { Mexx is relaunched as a standalone fashion label with a unique brand identity in Antwerp, London, Amsterdam, } \\
\text { Bruegge }\end{array}$ \\
\hline 2006 & $\begin{array}{l}\text { eShop is relaunch; New licensing categories include stationery and hair accessories; New lines added incluidng: } \\
\text { Sport Shoes, Fragrances, and Men's Bed \& Bath; Russia entry into Moscow and St. Petersburg; Appointment of } \\
\text { Jeff Fardell announced with a December } 1 \text { take over }\end{array}$ \\
\hline 2007 & New concept store opens in Amsterdam Kalverstraat; U.S. Stores close \\
\hline
\end{tabular}




\section{The Merger}

Strapped for cash and over 147 million Euros in debt, the Mexx team contemplated raising monies on the capital markets. However, Mexx postponed its IPO plans due to an unfavorable stock market climate and was, subsequently, taken over by Liz Claiborne, a New York based fashion group, in May 2001("Mexx in US Hands," 2001). Deemed "a marriage made in heaven" by Mexx (video), the acquisition was widely seen as benefiting both companies. Mexx could exploit Liz Claiborne's deep pockets to write off its debt, generate capital for continued growth and take advantage of existing contract manufacturing deals in the Far East. At the same time, Liz Claiborne could capitalize on Mexx's capable management team, European style, global presence and specialty chain experience ("Recent Buy," 2001). The merger would allow each company to adopt the best practices of the other (www.mexx.com). At the time of the acquisition, Liz Claiborne owned a portfolio of brands distributed primarily through US department stores, a mature industry. In contrast, Mexx was known as a younger, hipper brand compared to the traditional Liz Claiborne brands, "targeting a younger group with trendy clothes at moderate prices" that were labeled "edgier" than Liz Claiborne's traditional offerings ("Recent Buy," 2001).

The Mexx purchase was orchestrated by Liz Claiborne CEO Paul Charron, who had managed the company's growth from four brands to 33 since he took over the helm in 1995 ("Fashioning Liz Claiborne," 2004). The merger was designed to help Liz Claiborne reduce its dependence on department stores, a retail segment suffering from consumer buying shifts and declining volume. Purchasing Mexx and other specialty brands such as Lucky Brand Jeans in 1999, allowed Liz Claiborne to reduce its department store business to 49 percent of total sales in 2001 from 65 percent of total sales in 1999 ("Recent Buy," 2001). Liz Claiborne, reportedly, acquired all Mexx stock for 300 million Euro in cash (www.mexx.com).

\section{REORGANIZATION AND REALIGNMENT (2001-2007)}

\section{Continued Mexx Growth}

Mexx continued to grow and expand under the Liz Claiborne umbrella. In 2002, Mexx invested in expensive public relations extravaganzas in Amsterdam, Berlin and Maastricht; launched MexxColors, a cosmetic line in an exclusive deal with Etos pharmacies in The Netherlands; and introduced the first stand alone XX by Mexx store in Prague (www.mexx.com). In addition to introducing Mexx to the United States market by opening three stores in New York City, Mexx also launched the MexxSports Men concept store and XX by Mexx Jeans in 2003. The year 2004 saw Mexx debut a lifestyle magazine in four languages and open a high tech International Design Center in Amsterdam. The next year, Mexx opened an innovative new concept store on Oxford Street in London and further developed a premium jean line for women. In 2006, Mexx continued to form new partnerships, develop new product lines, and expand into new countries, such as Russia. Effective December 1, 2006, Jeff Fardell, formerly Vice-President of Global Apparel Sports and Culture at Nike, joined Mexx as Senior Vice-President and Managing Director of Mexx Brands. Mexx sales had grown to $\$ 1.25$ billion annually as Fardell joined the team (“Chada Taps Fardell," 2006).

\section{Growth of Liz Claiborne}

By 2004, Charron had added several brands to the Liz Claiborne mix such as Enyce (a hip-hop label), Juicy Couture, Ellen Tracy, Laundry and Sigrid Olsen ("Fashioning Liz Claiborne," 2004). Although Mexx had grown quickly, its strategy was fundamentally different from Liz Claiborne's. Mexx was known as a lifestyle brand with a distinctly European flair. Although both companies exhibited diversified product portfolios, Mexx's product lines were more fashion forward and its organizational structure was flat, lean and prepared to make strategy and product decisions quickly. Mexx had previously failed in its efforts to enter the US in the late 1980s/early 1990s by selling its brand through department stores. However, Liz Claiborne brands were primarily department store brands. While the company had enjoyed a fashion image early in its history, the Liz Claiborne Corporation was widely viewed in the industry as being burdened with a mix of boring, bland product lines that needed a drastic overhaul (Cordova, 2007). 
By the end of 2004, three Mexx stores had opened in the New York area with plans to rollout more ("Fashioning Liz Claiborne," 2004). Mexx's introduction into the US market was not without stumbles, according to CEO Charron. Mexx entered with holes in the product mix and a shortage of popular goods during the Christmas rush. "I think we've got a winner here. But we're going to have to work with it. This is a pretty significant undertaking," explained Charron ("Fashioning Liz Claiborne," 2004).

\section{Increasing Competition and Rapid Expansion}

At about the same time Mexx was moving into the US, two other European "fast fashion" brands - the Spanish retailer Zara and the Swedish retailer H\&M - entered the US in a big way. Both H\&M and Zara quickly gained popularity among youthful, fashion conscious US shoppers and were recognized for reacting to fashion trends by swiftly stocking hot items in stores. Both chains priced aggressively and were imitated by Liz Claiborne in selecting Mexx locations ("Fashioning Liz Claiborne," 2004).

The ninth US Mexx store opened in Paramus, NJ in 2005. Barry Zelman, the general manager of Mexx USA at the time, said that Mexx was in a different class than H\&M. He claimed the only common characteristic was that both chains originated in Europe but, unlike H\&M, Mexx was known for great fit and fine fabrics and finishes ("Mexx Opens First," 2005). Retail consultant, Candace Corlett, argued that Mexx competes with stores like Bebe for "that niche of the affluent trendy woman who feels that the Mexx look is her look, and has to have the real thing - as opposed to Mexx look-a-likes" ("Mexx Opens First," 2005). This point of differentiation was one that Mexx had carefully cultivated over its lifetime.

In early 2006, Liz Claiborne announced its pursuit of new growth opportunities in the Middle East and in the UK. The company entered into an exclusive agreement with MAF Fashion LLC in Dubai to be managed by Mexx's Europe Holding BV division ("Liz Claiborne Inc.," 2005). Management sensed an opportunity to establish Mexx brand equity in markets that had no dominant players. In addition, Paul Charron visited the UK to announce Liz Claiborne's expansion plans. "We're taking significant steps to more closely align our business with rapidly changing customer and consumer needs. We plan to capitalize on the many compelling opportunities among our more than 40 brands, including targeted brand extension and global retail expansion for 'power brands' such as Juicy Couture, Lucky Brand, Sigrid Olsen and Mexx," explained Charron ("Mexx Makes Moves," 2006). Charron further explained that the Mexx acquisition was strategic for the company due to Mexx's experience in fast paced product development and rapid time to market, a move Mexx deemed necessary to compete with the fast fashion models of Zara and H\&M (“Mexx Makes Moves," 2006).

Mexx reported that the brand was doing well in the UK due to its middle-market positioning, consistent pricing strategy and strong appeal to a less 'fashion-led' consumer. According to Ashish Sen Sarma, Mexx's VP Consumer Sales for Europe, "We really don't follow trends (Vickers, 2006)." London store openings, including a flagship store on Oxford Street, were followed by Mexx openings in Edinburgh, Scotland, bringing the total of freestanding UK stores to eight. Mexx also sold its products through the popular UK department stores, House of Fraser and John Lewis (Raikes, 2006). Mexx further expanded into the Baltic region in 2006, opening a total of three stores in Lithuania and Latvia ("Baltic Clothes," 2006).

\section{Values Eight}

Also in 2006, Mexx celebrated its $20^{\text {th }}$ anniversary with the production of both a video and a book. The anniversary was a perfect opportunity to tell the Mexx story to the world, focusing on the values and philosophy that drove Chadha to turn a $\$ 2000$ investment into a global brand worth more than 1 billion Euro and represented in 66 countries worldwide.

"While our company has many faces, carrying different brands, we are driven by a single soul - the one that has grown out of our key guiding principles," explained Chadha in the opening segments of Values Eight, the corporate video produced in 2006. Chadha built his organization on the following eight corporate values that also became the values of the Mexx brand: 
1. Fun - have fun in what you do

2. Nonconformist - think out of the box

3. Conscious - respect our community

4. Passion - strive to be the best

5. Proactive - the opposite of reactive

6. Responsive - focus on the consumer

7. Entrepreneurial - own your own job

8. Inspirational - optimistic, positive, search for personal growth

Several key Mexx associates featured in the video all told a similar story. To these associates, Mexx's culture was what made the company and the brand different and unique. Unlike some organizations, Mexx actually lived by all eight values. Living these values gave the company its strong identity and the brand its distinct personality (Video).

Mexx designers dared to be different. People throughout the organization were encouraged to share their vision and to give back to the community. The company culture was described as being intellectual and driven by dynamic energy. Mexx brought the consumer perspective into product design through a system of customer observation and hired designers with the same demographic composition as customers. The company believed it was delivering a lifestyle and knew it must fully understand the lifestyle to sell it. To support this position and gain a global competitive advantage, Mexx spent excessively on its distribution and information technology network.

\section{Reorganization}

While Mexx celebrated its 20 years of successes, the US retail landscape experienced a seismic shift when Federated Department Stores acquired May Department Stores Company, significantly consolidating the primary customer base for Liz Claiborne and its direct competitors. USA Today reported "a battle of the brands going on behind the scenes at a department store near you (O'Donnell, 2006)." This unprecedented consolidation in the industry left traditional department store brands like Liz Claiborne scrambling for new ways to compete.

During this time, the Liz Claiborne organization was also undergoing substantial reorganization. In the $4^{\text {th }}$ quarter of 2006, the company appointed William McComb as CEO to succeed Paul Charron, who was scheduled to retire. McComb had most recently served as Company Group Chairman for Johnson \& Johnson, a US manufacturer of consumer packaged goods ("Liz Claiborne Inc.," 2006).

Within a few weeks, Jeff Fardell was tapped as President of Mexx Europe Holding Co. to succeed Mexx founder, Rattan Chadha. Fardell announced, "The cornerstone of our business is the Benelux countries, including Germany and France. Russia is doing well but, as part of our pan-European strategy, we will be looking at southern Europe and the UK, for further expansion. There will also be a lot of activity in the US ("Mexx Readies," 2006)." As big changes took place in the executive suites of both Liz Claiborne and Mexx, Chadha, and his senior management team, prepared for their exit from Mexx.

\section{Enter the age of Franchising}

One way to compete in the new world of global retailing was to utilize a proven retail model - franchising. In early 2007, Mexx began to feature a program named Innovative Partner Store (IPS) in the UK and Ireland. This model was heralded as offering the advantages of franchising by reducing the key risks to the partner entrepreneur while providing the 'full support and know-how of a Mexx-owned store (“Mexx Appeal," 2007).'

\section{ROLE OF MEXX IN LIZ CLAIBORNE PORTFOLIO - CULTURE SHIFT (2007 AND FORWARD)}

The year 2007 marked major changes for the Liz Claiborne company under its new direction. In March of 2007, McComb announced plans to close the four remaining US Mexx stores, along with other underperforming specialty chains in the Claiborne mix (Butler, 2007). While McComb was closing Mexx stores in the US, he was also making plans to replace them with Juicy Couture and Kate Spade (purchased by Liz Claiborne in December of 
2006) stores while focusing on overseas expansion for Mexx and Lucky Brand stores (Butler, 2007). In a 2007 interview, McComb explained, “. $\ldots$ about $28 \%$ of the company's sales come from outside the United States. That's not enough. It's not like we're going to shrink our way to greatness. We're opening 100 to 125 stores this year (Butler, 2007)."

Investors initially digested the reorganization plans well; Liz Claiborne stock hit a record high of $\$ 46.84$ per share on Feb. 20, 2007 (Butler, 2007). However by mid-2007, McComb continued to discuss his plans to divest weak brands, company founder Liz Claiborne died of cancer, and the company lowered its annual per-share profit forecast (Burke and Coleman-Lochner, 2007). Analysts reported that a power struggle with Macy's, following its purchase of May Department Stores, had forced Liz Claiborne to act faster to divest its weak brands, profits dropped by a substantial 65 percent in $1^{\text {st }}$ quarter 2007, and sales declined by 2 percent. Stock market prices began a tumble from the $1^{\text {st }}$ quarter high and restructuring resulted in the loss of some stalwart Liz Claiborne executives (Cordova, 2007).

\section{Re-branding Mexx}

Already partnered with Majid Al Futtaim (MAF) Group in Dubai, Fardell announced the Fall 2007 opening of a new Mexx concept store in Dubai's Deira City Center. Due to Mexx's slowing growth in Germany, France and the UK, Fardell anticipated tremendous growth in the Middle East with more stores scheduled to open in 2008 (Interview, Blizzard, 2007).

Fardell also debuted the "re-invention" of the Mexx brand in response to increased competitiveness in the industry over the last five years. According to Fardell, Mexx's efforts would focus on building a community around the brand and presenting a stronger point of view. Consumers should view Mexx as European, contemporary and stylish across all types of apparel - casual, business and formal. The new Mexx proposition would cultivate a 'Smart Look' for customers (Interview, Blizzard, 2007).

Fardell explained that he considered Zara and $H \& M$ to be about fast fashion, while Mexx was about style. The goal was to position the Mexx brand as a means to achieve effortless style and to double Mexx's business in five to six years with the theme, "Mexx makes style easy for me!". Fardell described the brand's re-birth as defining what the brand is and its core markets, which would be the focus of Mexx's immediate resources. He acknowledged that this repositioning was a reaction to the past two years when Mexx had lost momentum as growth slowed. The Mexx repositioning came about, in part, due to a redefinition of the Liz Claiborne strategy. In the wake of declining department store sales, Liz Claiborne announced that it was in the process of divesting 16 of its 48 brands, with the intention of focusing on the four power brands of Juicy Couture, Kate Spade, Lucky Brand Jeans and Mexx (Interview, Plumbridge, 2007).

According to Fardell, a brand must evolve to survive, so great strategies need an element of flexibility. Fardell found inspiration for the Mexx brand evolution from the outside, looking to Starbucks to provide insight about location decisions and to Nike for insight about obsession around principles. Fardell pinpointed Zara as providing Mexx with the biggest challenge. Fardell explained, "It's less about creating ideas and more about looking at others' ideas and using them (Interview, Plumbridge, 2007)."

\section{A Difficult Environment}

According to Women's Wear Daily, the fashion world's most influential trade journal, the Mexx brand did not resonate with American consumers, and the company was forced to shutter all 11 US Mexx stores in 2006 and 2007 (Creevy, 2007). Liz Claiborne's McComb pointed to the US housing slump and credit crunch as stifling consumer spending (Gerwitz-Ward, 2007). In an effort to turn around the company, popular designer Isaac Mizrahi was named creative director for Liz Claiborne in January 2008, although at least one analyst suggested that one individual, even someone of Misrahi's stature, could not bring Claiborne back to its fashion heyday (Gerwitz-Ward, 2007). Meanwhile, Liz Claiborne began unloading product lines by selling Ellen Tracy, prAna, Laundry By Design and C\&C California and closing Sigrid Olsen (PR Newswire, 2008). 
Mexx closures were not limited to the finicky US market. In February 2008, Mexx announced that it was halting all UK operations, closing 61 retail outlets, eliminating 300 jobs, and pulling out of 58 shop-in-shop arrangements in UK department stores, John Lewis and House of Fraser ("Mexx Readies," 2006). Some analysts blamed the Mexx failure on the company's inability to compete with Zara and H\&M; others cited depressed UK and US economies coupled with oversaturated retail markets; and still others claimed that Mexx lacked brand awareness and product distinctiveness (Butler, 2007; Burke and Coleman-Lochner, 2007). One analyst noted that McComb acted appropriately to focus on Claiborne's four power brands although cautioned that consumers spend less on "aspirational" products in a weak economy (O'Connell, 2007). Exhibit 3 compares Mexx number of stores and sales with H\&M and Zara.

At the company's May 2008 stockholder meeting, McComb said, "As painful and visible as this restructuring has been, we're convinced that our actions will serve shareholders well. During these increasingly difficult times, we focused on implementing the changes that we need to prepare the business to lead once again" (Cordova, 2008). However, business analysts were not as optimistic as McComb.

In mid August 2008, LIZ shares sold for under $\$ 13.00$ and analysts voiced skepticism about the company's ability to carry out its ambitious turnaround strategy (Cordova, 2008; Gellar, 2008). Analysts suggested that it was quite difficult to see the "light at the end of the tunnel" for a successful Mexx turnaround in the foreseeable future, "given the deteriorating Western European macro environment and tough competition from Zara and H\&M" ("Liz Claiborne Inc.," 2008).

Exhibit 3 - Zara, H\&M and Mexx Comparison

2008

\# of Stores:
H\&M
Zara
Mexx:
Specialty Retail
Outlets
Concessions

Sales (millions US dollars)
H\&M
Zara
Mexx

But the fashion industry always has a new player entering the picture or an old player repositioning. The new: Sandwich, labeled as the latest retailer you've never heard of, opened its first US store at the Las Vegas Fashion Show Mall in July 2008. Sandwich, another Netherlands-based specialty retailer, is looking to break into the US fast-fashion, mid-price range market (Edelson, 2008). The old: Gap put a new design chief on board to reinvigorate its tired brand. The "new" Gap identified 25- to 35-year-olds as its target for "classic American apparel with a modern twist" (Porter, 2008).

\section{CONCLUSION}

Fardell marveled at the Olympic pageantry on TV the night of 08-08-08 as he outlined options for Mexx's future. The issues he struggled most with revolved around how, as Mexx Europe's President and CEO, he should go about making decisions related to:

- $\quad$ Growth options - where, when and how fast

- $\quad$ Business model options - partnerships, licensing arrangements, franchises 
- $\quad$ Brand strategy - what is Mexx's image in the marketplace, is that image consistent across markets, and who do customers see as Mexx's direct competition

- $\quad$ Corporate culture - does the work environment reflect the corporate culture that Mexx believes it has and is that consistent with the culture at its parent company

He needed to move quickly in this rapidly changing and highly competitive environment.

\section{ACKNOWLEDGEMENTS}

The authors would like to thank the following University of Tampa graduate students for their help in preparing this case: Lena Cabrerra and Kelly Russell.

Research support for this case was provided by U.S. Department of Education Title VIB.

\section{AUTHOR INFORMATION}

Dr. Judith Washburn, (Associate Professor, Marketing), University of Tampa, John H. Sykes College of Business. Before joining UT in 2003, Dr. Washburn was an assistant professor of marketing at Bowling Green State University in Bowling Green, $\mathrm{OH}$, and an instructor of marketing at Southern Illinois University at Edwardsville. She teaches a variety of both graduate and undergraduate marketing courses. Dr. Washburn publishes regularly in academic journals and frequently presents her research at academic conferences. Her research interests include branding, associative relationships between businesses and nonprofit organizations, service value, and university marketing.

Dr. Hemant Rustogi, (Chair/Professor, Marketing; Coordinator, International Business), University of Tampa, John H. Sykes College of Business. Dr. Rustogi specializes in market research, international marketing, service quality, marketing strategy, and international business education. Dr. Rustogi has written numerous publications on marketing and international business education. His efforts were instrumental in helping UT earn $\$ 1.5$ million in federal grants for international business education. Dr. Rustogi is the CEO for the Brandon Montessori School.

Rebecca Dearth, (President), Advantage Pointe Internationale, LLC, 301 W. Platt St., Tampa, FL 33606. Rebecca earned a Master of Business Administration and Bachelor of Science in Marketing from The University of Tampa. She has worked in consulting since 2004, specializing in developing promotional strategy and marketing communications and conducting marketing research. She also serves as Marketing and Operations Director of RedRoom Recorders, Inc., and is an active blogger and talented artist.

\section{BIBLIOGRAPHY}

1. "Baltic Clothes Retailer Apranda Buys Mess Business in Latvia," Baltic News Service, (August 24, 2006).

2. Burke, Heather and Lauren Coleman-Lochner. "National Post's Financial Post \& FP Investing," Bloomberg News, (July 12, 2007).

3. Butler, Elisabeth. "Liz Claiborne shedding excess," Crain's New York Business, (March 5, 2007$), 1$.

4. "Chada Taps Fardell to Head Mexx Europe," Women's Wear Daily, (November 13, 2006).

5. Cordova, Elisabeth Butler. "Claiborne plans belt-tightening," Crain's New York Business, (July 9, 2007), 1.

6. Cordova, Elisabeth Butler. "Liz Claiborne downgraded on retail woes," Crain's New York Business, (July 9, 2008).

7. $\quad$ Creevy, Jennifer. "Eurovision," Retail Week, (May 4, 2007).

8. $\quad$ Edelson, Sharon. "Foreign Retailers Flock to U.S.," WWD, (August 4, 2008).

9. "Fashion Group Mexx Plans Amsterdam IPO," AFX News Limited, (March 15, 2000).

10. "Fashioning Liz Claiborne Boom," Daily News, L.P., (February 9, 2004).

11. Gellar, Martinne. "Liz Claiborne Shares Tumble on 2008 View," (August 13, 2008).

12. Gewirtz-Ward, Lisa. "Liz Claiborne may shed 16 brands," Daily Deal/The Deal, (July 12, 2007).

13. Interview with Phil Blizzard, M 9/24/07 AME Info Radio 
14. Interview with Jeff Fardell 01/10/07 - Sacha Plumbridge, http://www.dubaipod.com/Default.aspx?PodId=193

15. Interview - Ashish Sensarma. Interviwed by H. Rustogi. September 2006.

16. "Liz Claiborne Inc. Names William L. McComb Chief Executive Officer," Business Wire, Inc., (October 16, 2006).

17. "Liz Claiborne Inc. Pursues Growth Opportunity in Middle East," PR Newswire Association LLC., (February 6, 2005).

18. "Liz Claiborne Inc. Reports $2^{\text {nd }}$ Quarter and Fist Six Months Results," PRNewswire - FirstCall, (August 13, 2008).

19. “Mexx Appeal," Business Franchise, (March 2007).

20. "Mexx in US Hands," Financial Times Information, (May 17, 2001).

21. "Mexx Makes Moves into Fast Fashion,” Just-Style.com, (July 21, 2006).

22. "Mexx Opens First North Jersey Store in Paramus," KRTBN- The Record- Hackensack, (May 6, 2005$).$

23. "Mexx readies for European expansion," Retail Week, (November 17, 2006).

24. "Mexx Sees Profit Rise 60\%," Financial Times Information, (February 22, 2001).

25. O’Connel, Vanessa, “Affordable Luxury Stores Feel Economy’s Pinch,” 11/09/07. nline.wsj.com/public/article print/SB119456835990487306.html

26. O’Donnell, Jayne. "Competition grows as brands lose places to hang their wares," USA Today, (August 29, 2006), 1B.

27. Porter, Jane. "A Fashion Guy Gets Gap Back to Basics,” Businessweek, (August 18, 2008) 56-57.

28. PRNewswire-FirstCall, 01/08/08, http://www.lizclaiborne.com/

29. Raikes, Sally. "Lets' Talk About Mexx," Scotland on Sunday, (August 6, 2006), 14.

30. "Recent Buy of Trendy Dutch Outfit Should Wear Well on Liz Claiborne," Investor's Daily, Inc., (July 11, 2001).

31. Vickers, Emma. "Mexx rolls out trading web site as UK sales continue to deliver," Retail Week, (August 4, 2006).

32. Video. "Mexx Europe Holding BV." Copyright 2006. Values Eight - The Director's Cut. Corporate Values. 